\title{
The Historical Significance and Role of the Kola Nut among the Igbo of Southeastern Nigeria
}

\author{
Ikenna Ukpabi Unya \\ https://dx.doi.org/10.4314/jrhr.v13i1.13
}

\section{Abstract}

There are many customs and traditions that have effectively given the Igbo of Southeastern Nigeria group identity and social cohesion. And the kola nut is one of those realities. However, it is not only the Igbo that cherish and reverence the kola nut. In fact, kola nut is a highly prized fruit among the people of West Africa where its importance is seen in the social and religious customs of the people. But the Igbo lay special claim to kola nut and view it as the king of all fruits on earth because of the roles it play; hence, the kola is seen among the Igbo as a symbol of acceptance, cooperation and solidarity. Thus, the objective of this study is to examine the historical origin of the kola nut based on the Igbo ancestral myths and the symbolic interpretations of the different lobes of the Cola acuminata. The study will also investigate the significance and functions of the kola nut and how the influence of modernization is eroding its traditional values. The study is basically qualitative. It utilized existing literature on kola nut with oral sources in order to enhance our knowledge on kola nut. The study's findings reveal that kola nut consumption and functions are part of Africa's indigenous traditions that survived colonial intrusion, although the influence of modernization is greatly threatening the ritual functions and the traditional values. The study, thus, concludes by recommending that the Igbo should restore the significance and values of the kola nut by planting more kola nut trees in order to increase its availability and affordability as a source of hospitality and acceptance. Again, the Igbo communities and leaders should create a platform where the origin, significance and values of the kola nut must be taught and passed from generation to generation. 
Unya: The Historical Significance and Role of the Kola Nut among the Igbo of Southeastern Nigeria

Keywords: Kola Nut, Significance, Role, Igbo, Nigeria.

\section{Introduction}

The Kola nut is the fruit of the kola tree and is regarded as a fruit of great importance in West Africa where it serves different purposes among the different ethnic groups. Kola nut is not only grown in West Africa but is also indigenous to the sub-region of Africa. While describing the kola nuts and their different species, Quarco ${ }^{1}$ asserts that kola nut belongs to the plant family Sterculiaceae, having about 125 species of trees native to the tropical rainforests of Africa, and that it occupies a unique place amongst West Africans where it is widely consumed by them. It is of particular importance in the social life and religious customs of people in the tropics of West Africa.

Kola is prized throughout West Africa by the poor and the affluent; by men and women; by Muslims, Christians and animists. It is a shared experience, a powerful cultural symbol. It is given to show respect and as a sacred offering. It is a crucial part of community meetings. It is incorporated into many rites of passage and into ceremonies to cement treaties and contracts ${ }^{2}$. Commenting on the centrality and importance of kola nut among West Africans, Sprague 3 reports that one Portuguese explorer who visited the West African region in 1587, observed that many people he encountered in his travels used the nut to relieve thirst and improve the taste of water by chewing it. Other similar journals by explorers noted these same medicinal properties and also documented African practices such as using the nut to strengthen the stomach and combat liver disease.

In Nigeria, kola nut is not only grown in large quantities but is also articulated as a fruit of primary importance in the life of the people because of its many roles. Thus, Nigeria is the highest producer of kola nut in West African region. Quarco ${ }^{4}$ reports that about $90 \%$ of the kola produced in Nigeria is consumed within the country while $10 \%$ is exported. According to Asogwa, Anikwe and 
Mokwunye ${ }^{5}$, there are abundance of soils of high, medium, and low fertility that can be strategically exploited for kola nut cultivation in an effective land utilization policy in Nigeria. Such suitable soils have long been identified in the following parts of the country: (1) southwestern states, (2) Edo State (most of the southern part), (3) Delta State (most of the non-riverine areas), (4) southeastern states, (5) Cross River State (most parts of the state), (6) Akwa Ibom State (most parts of the state), (7) Rivers State (the non-riverine areas), (8) Kwara State (Ilorin area), (9) Kaduna State (Zaria area), (10) Adamawa State (the southern parts of the state), (11) Kano State (areas around rivers and streams if irrigation is provided, especially during establishment stages), (12) Niger State (Mokwa and large areas of the upper part of River Niger, provided irrigation is available), (13) Benue/Plateau/Kogi States (Oturkpo and Kabba areas, and (14) Nassarawa State (Lafia area).

Among the Igbo people of Southeastern Nigeria, kola nut is something bigger than that popular seed crop tree grown in the Central and Western part of Africa. The traditional oral history of the Igbo claims that the kola nut tree was the first tree on earth and therefore, its fruit, the first on earth. This belief might have been the reason whyBasden ${ }^{6}$ declared that kola nut is neither the biggest nor the sweetest fruit in Igboland, but that the nuts have tremendous cultural significance. This explains why kola nut is ritualized among the Igbo people of Nigeria and is specifically men's affair. It is a highly prized cultural symbol that is revered and celebrated in every significant gathering among the Igbo. According to $\mathrm{Nwachukwu}^{7} \mathrm{kola}$ nut is seen as food, and as such, attended with deserving feast. As a food, kola nut is eaten with relish. Emotional and cultural attachment to kola nut in Igboland makes it religiously infectious. Adherents of the culture of kola nut, which without exaggeration involves every Igbo of religious belief, gender and caste find in the kola nut lobes a cultural vehicle that conveys the people's world view. Thus, the kola 
nut is to the Igbo people what the prayer book stands for in the Christian world. It is this all-encompassing role of the kola nut that made Obineche ${ }^{8}$ to assert that the kola nut has ritual powers for peace, long life, prosperity, and unity; also used for sacrifices and functions, as a facilitator of communication between men and the gods. As a result of these functions, Achebe ${ }^{9}$ described kola nut among the Igbo as a sacred fruit that has distinguished role to play in Igbo life and culture.

To be sure, in Igbo cosmology and philosophy, the kola nut is seen and described as a king. This is because it always comes first in every social gathering. It is used to welcome guests during meetings or public gatherings, used for marriage ceremonies, title-taking, oath taking, sacrifices and others. Kola nut is often presented to guests and is viewed as an unavoidable gesture expected from a host. No matter the extent of cordiality shown by a host and no matter the type of delicious meal served to a visitor, he will feel unwelcome if he is not presented with kola nut. Thus, the Igbo people according to Kammampoal and Laar $^{10}$ honour and love kola nut because of its socio-cultural significance. In West Africa where it is cultivated on large scale, its value varies from one community to another. For instance, in predominantly Muslim Hausa as well as Yoruba communities, kola nut is offered as a symbol of hospitality; but without elaborate ceremonies like the Igbo.

It was this central role the kola nut plays that led to this saying among the Igbo that "kola nut is cultivated in large quantities in the Western Nigeria, consumed greatly in the North and valued and respected among the Igbo of the Southeast". Therefore, this study aims at examining the significance and values of the kola nut among the Igbo people. The analysis will focus on the kola nut and its multiple uses; its social, spiritual and economic functions in the Igbo cosmology. To achieve this objective, the study will be divided into sections. With this introductory overview, the study proceeds into 
investigating the origins of kola nut among the Igbo; the third section examines the symbolisms of kola nut; section four investigates the values and roles of the kola nut, section five discusses the influence of Western civilization on kola nut while section six concludes with recommendations.

\section{The Igbo Historical Origin of Kola Nut}

Although it has been established that the kola nut is indigenous to West Africa and that it has many species, but the most common species in Nigeria are Cola nitida and Cola acuminata. Cola nitida (gworo) has only two cotyledons. According to Ukaegbu ${ }^{11}$ in Igbo traditional rituals and ceremonies, gworo (Cola nitida) is not valid: only the Igbo kola (Oji Igbo) Cola acuminata is acceptable. The reason for this distinction will be made clear when Igbo kola nut symbols and interpretations is treated.

To be sure, most regions in Africa depend on oral traditions for the reconstruction of their early histories. As a matter of fact, African history was basically oral until the $20^{\text {th }}$ century when African historians started documenting the history of their people by themselves. Thus, oral tradition and source can be described as historical events of previous generations handed down and narrated from generation to generation. The beauty of oral tradition is that it offers insights into the cultural values of a people and adds information about the past for the historian. Therefore, the historical origin of the kola nut among the Igbo is largely based on oral sources.

According to the tradition of origin of kola nut among the Igbo, there was a special relationship between humans and the spirit beings. Obineche $^{12}$ apparently quoting Onwu-Otuyelu ${ }^{13}$ asserts that in the beginning of time, the living world (man) was related to the spiritworld --- that man and sprits were interacting to the level of exchanging ceremonies and festivities like sports competitions. In one of these competitions - (wrestling), one spirit-being called Aji Ike 
Unya: The Historical Significance and Role of the Kola Nut among the Igbo of Southeastern Nigeria

Ugburuoba stood unconquerable by any human wrestler. In those days, sports heroes easily attracted the love and affection of the opposite sex. As such, women within the human world began to fall in love with this spirit hero, Aji Ike. Prominent among these women was Ugo Onobo who was so obsessed and madly in love that she eloped with Aji Ike Ugburuoba to his spirit abode located at the depth of the Cross River at Okwuruike. This sudden disappearance of Ugo Onobo posed a nightmare not only to her two elder brothers - Agala and Ogbu Onobo, but to the entire community who did not give up in search for her. To the two brothers, the search became more imperative when they were openly ridiculed in the village square for being weaklings because of their inability to locate their one and only missing sister, Ugo.

This challenge became so unbearable that Ogbu Onobo and his brother Agala vowed to stop at nothing till they had found their only sister, Ugo. The search led them to a diviner (dibia) to inquire of her whereabouts. Their hope was elated when the diviner told them this:

By the time chicks start returning to their roost and the sun is gradually sinking close to setting (about $4 \mathrm{pm}$ ), go to the brink of the Cross River Okwuruike during ebb-tide there, stand and call loudly the name of your sister, Ugo Onobo, seven times and she will answer. Then follow the echo of her voice; it will lead you to the bottom of the Cross River. There, you will find her living with Ajike Ugburuoba, the Great Spirit wrestler ${ }^{14}$.

The two brothers complied strictly with the directives of the diviner and behold they found their sister with Aji Ike Ugburuoba. On entering the house, they found their sister pregnant. In excitement, for the visit of his brothers-in-law, Aji Ike went into his room and came out with native chalk $(\mathrm{Nzu})$, coconut with water as drink and kola nut. The chalk, he gave them to smear on their left wrist as a welcome gesture; the coconut with its water, he gave as drink and food; and the 
kola nut, he gave them as dowry for their sister, Ugo. In anger, the two brothers rejected these offers but demanded to take their sister home even with the pregnancy. The helpless Aji Ike consented to their request but pleaded with them to accept his gesture of hospitality. He told them to go home with their sister, though pregnant, but along with the presentations. When you get home, he said, "use the chalk to welcome your guests as I did to you, to tell them how glad I was when you visited me; plant the coconut and when it grows and bears fruits, take one, break it into four parts and leave it broken on the road. By this act, you have given me my own share of it and then you can eat the rest of it and subsequent harvests with your families and guests".

Concerning the kola nut, he instructed them to plant also, but when it bears fruit and it is harvested, they should break the pod, pick one of its seeds with four divisions signifying the cotyledons (lobes or eyes), these they shall hold in their left hand, cast with a statement of thanks and in so doing, Aji Ike said, "you have given me my share. Then break and share the rest with your guests". He continued, "as I have presented you the kola nut as dowry on the head of your sister, Ugo, so must you present kola nut with regard to every marriage in every human home as the celebration between the world of the living and that of the spirits". Although Aji Ike took back the baby from Ugo through miscarriage on the Ndele Bridge, the two brothers performed the rituals as Ajike directed. As for the red colour of the kola nut, the legend attributed that to Agala Onobo's blood that stained red some of the seeds in the process of breaking the first product of kola nut in the land of the living. While some of the white colour seeds are called $O j i \mathrm{Ugo}$ as a reference to Ugo Onobo who was the first woman ever to have kola nut as her bride price.

From this myth on Igbo origin of kola nut, one can therefore understand the reason why there is a popular etymology among the Igbo that $O j i$ (kola nut) means $\mathrm{O}=$ Omenala (custom); $\mathrm{J}=$ Jikotara 
(that unites); I = Igbo. Thus, oji means “omenala jikotara Igbo", that is, "Custom that unites the Igbo". Therefore, the kola nut is articulated among the Igbo as a valuable fruit of great importance in the whole livelihood of the Igbo community; for it offers to play a role of unity, harmony and solidarity. Another significance associated with the myth is that it gives credence to the Igbo preference of Cola acuminata, the specie that has more than two cotyledons and furthers why the specie has two colours - white and red. The white is called Oji Ugo. Ugo means eagle in Igbo, but this does mean the eagle kola, rather, Ugo here represents the legendary Ugo Onobo, the first human wife of the spirit wrestler, Aji Ike, for whom kola nut was presented to the living brothers by the spirit husband. The red colour kola nut is attributed to the legendary Agala Onobo's blood that stained some kola nut seeds in the process of breaking the very product of kola nut harvest in the land of humans ${ }^{15}$.

\section{Kola Nut Lobes: Significances and Interpretations}

In Igbo cosmology, Cola acuminate (Oji Igbo) is the officially recognized kola nut that has cultural significance and attachment. However, Cola nitida (gworo) is also consumed by the Igbo especially during social gatherings along other entertainment fruits such as garden eggs and bitter kola but no special cultural value is attached to it. Cola acuminata (Oji Igbo) is the type that has different cotyledons and each lobe represents different meaning and interpretations. And the classifications are as follow:

1. Most Igbo scholars do not start their categorization of the kola nut with the type one cotyledon, reason being that a kola nut with single cotyledon is rare in Igboland. If by default, a kola nut with single lobe is seen, it will be treated as sacrilege because it signifies a taboo or abomination of the highest order. Thus, it is called Oji Ogbi (dumb kola nut), or Oji Agbara or Oji Mmuo (kola 
nut of the spirit) and must be discarded or thrown away because it is not for human consumption.

2. Two lobed kola: Kola nut with two cotyledons is also seen as $O j i$ Agbara. This is because in Igbo cosmology, the number two lacks balance and thus regarded as unstable and that may be the reason why twins were killed in the pre-colonial Igbo era. Thus, the Igbo avoid kola nut with two cotyledons and associate it with bad omen.

3. Three lobed kola: The kola nut with three cotyledons is called Oji Ikenga or Oji Ike (kola nut of the valiant). This is where the positive interpretation of the Cola acuminata begins. Oji Ikenga signifies good omen typical of the structure of the Igbo family with the male elder as leader in order of father, mother and children.

4. Four lobed kola: The kola nut with four cotyledons is called Oji Udo na Ngozi which means "kola nut of peace/harmony and blessing". The number four is a very sacred number in Igbo culture as it symbolizes the four traditional market days that mark the Igbo week: Eke, Orie, Afor and Nkwo. According to Umeogu et $\mathrm{al}^{16}$, a four lobed kola symbolizes the blessings attached to the principle of the four market day cycle, this is because in the Igbo business cosmology, the market cycle allows each community dedicated to a particular market god to have a day in which her agricultural produce is brought to the market to be patronized by other neighbouring communities while the cycle rotates fairly every four days (the traditional week length in the Igbo calendar).

5. Five lobed kola: Kola nut with five cotyledons is called Oji Отити (kola nut of increase in procreation, prosperity, protection and good luck). It also symbolizes abundant harvest, which the Igbo interpret as wealth, increase and multiplication of children. 
Expectant parents and the newly married especially men, will always crave to partake of this kola ${ }^{17}$. Five lobed kola does not appear frequently in social gathering. Therefore, anytime it occurs, the Igbo people view it as a sign of blessing and prosperity.

6. Six lobed kola: Kola nut with six cotyledons is often rare, but when it occurs, it is a symbol of covenant or communion between the gods and men. It is called "OjiOgbugbandu", (kola nut of covenant or bond with the ancestors). It should be noted that the smallest cotyledon of this kola nut is thrown to the ancestors to show the direct link between the living and the dead in Igbo cosmology ${ }^{18}$. Generally, it is a hard-to-find kola but its appearance symbolizes special visitation by the gods on the man that prayed which is manifested by extreme prosperity and blessing on the man who broke the kola which is usually celebrated by killing something with blood like chicken or goat ${ }^{19}$.

7. Seven lobed kola: Kola nut with seven cotyledons is called "Oji Asaa-asota (kola of seven and eight). It represents joy and happiness and generally regarded as a symbol of royalty. According to Umeogu et $\mathrm{al}^{20}$, the seven lobed is extremely rare but appears in a long while especially during a most difficult situation. It is highly associated with supernatural effects because it represents the four gods of the market days, the four day week cycle, the three dimension of man and the trinity. These spiritual symbols make it the most cherished and the most valuable sign of good omen. 


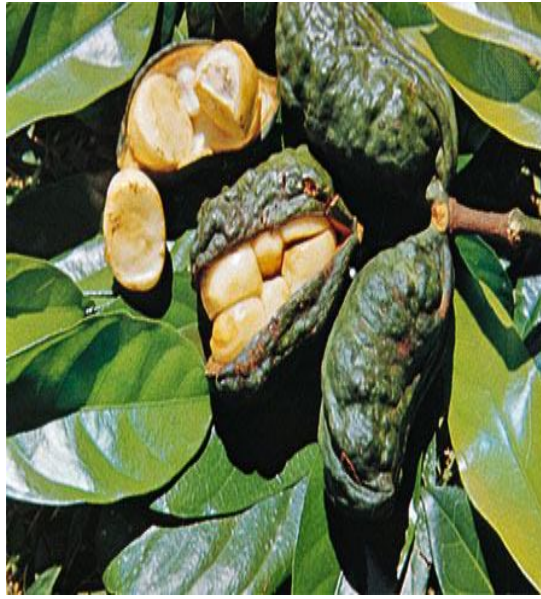

Kola nut being harvested from the pod

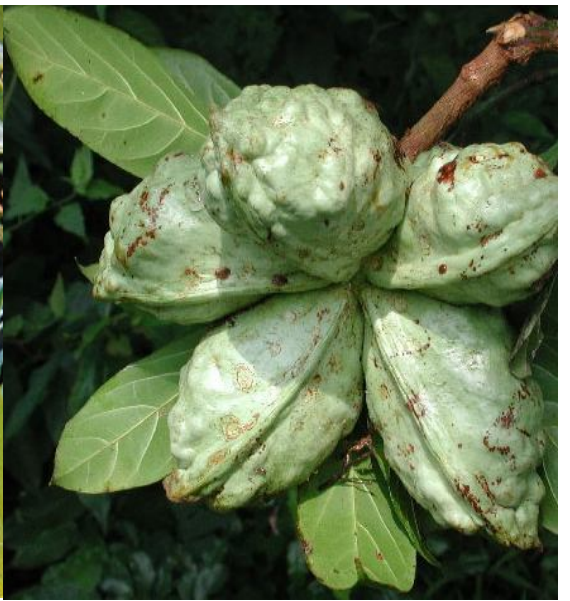

Kola nut still intact on the pod

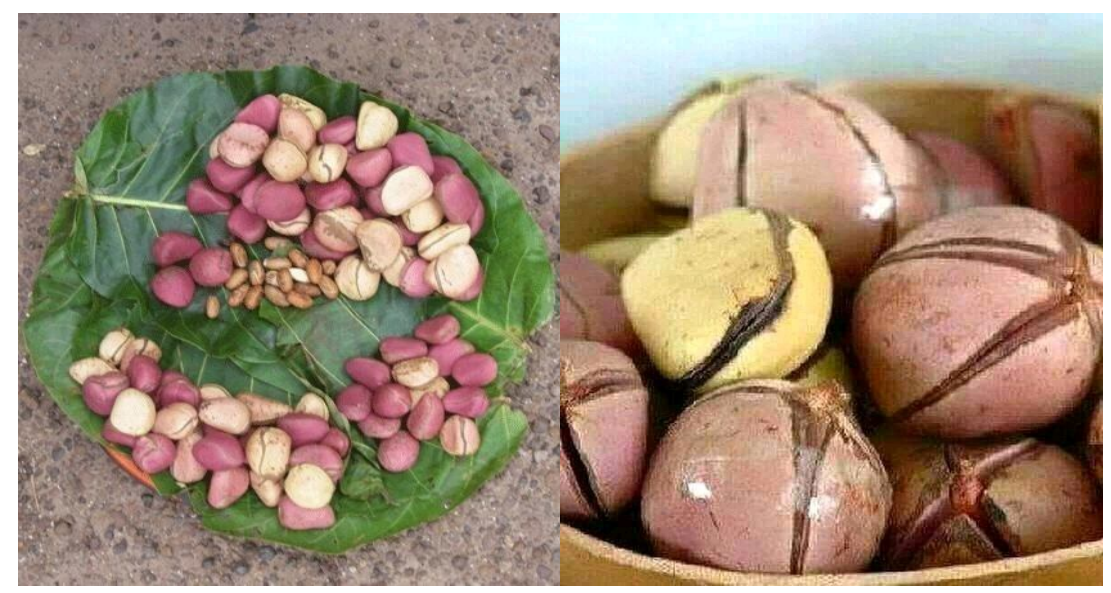

Cola Nitida

Cola Acuminita 
Unya: The Historical Significance and Role of the Kola Nut among the Igbo of Southeastern Nigeria

\section{Presentation of the Kola Nut among the Igbo}

The African tradition has undergone significant upheavals in terms of religion, social structure, language and values; but the kola nut presentation, breaking and eating is one of the cultural heritages of the Igbo that had withstood all manners of encroachment and intrusion by the European forces of development, urbanization and religion. In Igbo culture, the kola nut is a crucial part of many ceremonies, gatherings, and welcoming of visitors to one's home. As a mark of respect, the kola nut is broken with a knife and then followed immediately by prayers. Once the kola nut is broken; its pieces are distributed to everyone starting with eldest, by the youngest among them. When kola nut is present, the host hands it to the oldest man among his guests. The oldest man then shows it to everyone present and then passes it around and when each of them records his approval by touching the nut, greetings and prayers are said to God Almighty, the gods as well as the ancestors. Prayers are usually for life, happiness, good health, children, prosperity and good harvest. It is a fact that the blessing of the nut is exclusively done by the old who are known for their mastery of oratory in their effort either to express an act of gratitude or give praise to the Almighty - Supreme God, the gods, deities, goddesses as well as ancestors in a special language ${ }^{21}$.

According to Ezeugo ${ }^{22}$, the presentation of kola nut is an evidence of social harmony, love and happiness for one another. Thus, he compares the presentation and breaking of the kola nut to the Catholic sacramental communion, and calls the kola nut the 'bread' of Igbo sacramental communion which must be carefully and specially presented, blessed, shared and partaken by all the parties and families in every ceremony. Commenting on the processes involved in the presentation and sharing of the kola nut in Igboland, Basden ${ }^{23}$ asserts that the Igbo welcome is not complete without the sharing of the kola nut. According to him: 
Immediately after the prolonged greetings in the traditional manner, the kola nut is brought forth on a dish or saucer or, what is more correct, on a wooden platter (really a small box fitted with a vocer) prepared and kept for the sole purpose of presenting kola nut. In the dish are one or more nuts. The owner first receives it from the slave attendant or one of his wives. He takes a nut and puts it to his lips, thus signifying that it is about to be offered in good faith. This symbolic action proves him to be free from malice. The dish is, thereupon, passed to the visitor.

Moreover, the beautiful symbolism of kola nut presentation in Igboland comes out clearly in the presence of many visitors or group. The fullness of the social aspect comes clear as the kola begins its journey from one person to another according to the closeness of kinship relationship from the home of the host and spreads out to different directions within the audience and returns back to the host. This is called Ire Oji - selling of kola. When it comes back to the host, there is a saying that Oji Eze n'Eze n'aka (the King's has returned to the King). This symbolic presentation is a kind of headcount in a way of identifying all the people in the audience before any type of discussion could be heard. This manner of kola nut presentation in Igboland is very technical in the sense that any mistake made while carrying the kola nut around the gathering attracts a penalty or spells a feeling that the offender is irresponsible, uncultured or may not be reliable. In some cases, the offender is asked to pay some token for violating the rule of kola nut presentation ${ }^{24}$.

\section{Igbo Kola Nut as a Source of Cultural Identity}

Kola nut is an ordinary fruit but it serves as a great symbol in bringing a people closer or together and thereby foster unbroken relationships among the Igbo both within and outside Nigeria. Therefore, the kola nut is symbolic in the following ways: 
Unya: The Historical Significance and Role of the Kola Nut among the Igbo of Southeastern Nigeria

i. Acceptance: The kola nut is an indispensable fruit among the Igbo because, the presentation and sharing of kola nut symbolizes unity, love, peace, kindness and gratitude. Obineche ${ }^{25}$ asserts that kola nut is a symbol of friendship which any host can show among the Igbo even though the monetary value of kola nut is relatively cheap. The inability of a host to either present kola nut or to render an unalloyed apology for his inability to provide kola is interpreted as a sign of unacceptance. In some cases, a guest may not disclose his mission until after the kola nut has been presented to him. Thus, this acceptance is shown by the proverb among the Igbo that he who brings kola nut brings life. Similarly, the hospitality, the acceptance of kola nut offers is equally the same as the shame the rejection of kola nut brings. In Chinua Achebe's Things Fall Apart, in chapter four, when Okonkwo beats his wife during the Peace Week, the priest of Ezeani refuses to share hospitality with him and boldly tells Okonkwo: "Take away your kola nut. I shall not eat in the house of a man who has no respect for our gods and ancestors" 26 . The shame of one's kola nut being rejected was enormous and anybody whose kola nut was rejected especially by the elders of the land must do everything possible to atone for his transgressions.

ii. Cooperation: The kola nut wherever it is presented is a sign that parties who have gathered are willing to cooperate among themselves for their common good. It is usually eulogized with the words: "Egbe bere, Ugo bere" (live and let live). ${ }^{27}$ Again, Achebe's Things Fall Apart comes in to show us how the Igbo maintain social cooperation via kola nut fruit. In chapter 3 of the novel, the importance of kola nut and how it enables the Igbo to conduct their affairs is observed, for Okonkwo had approached the wealthy Nwakibie to ask for yam seed to start his business, as he had inherited nothing from his father, Unoka. On his arrival, two elderly neighbours were sent for and the two sons of the old man were present with him in his Obi (house). 
Nwakibie presented "a kola nut and an alligator pepper, which were passed round for all to see and returned to him". He broke the nut saying:

We shall live. We pray for life, children, a good harvest and happiness. You will have what is good for you and I will have what is good for me. Let the kite perch, let the eagle perch too. If one says no to the other, let his wing break ${ }^{28}$.

After the kola nut had been eaten, Okonkwo brought his palm wine. In an exchange with the wealthy farmer on the issue of borrowing yam seed, Okonkwo uses a proverb to sustain his love for hard work and promises to pay back. Nwakibie responded by saying that: "as our father said, you can tell a ripe corn by its look. I shall give you twice four hundred yams" ${ }^{29}$.

iii. Solidarity: Beyond acceptance, the kola nut further signifies a show of solidarity,

communality and unity of purpose. As kola nut is broken, it fosters love, peace and openness among the group. Whenever the Igbo are gathered even in faraway distant lands of Europe, Asia and America, the truest symbol present is the Oji Igbo. It is both a cultural identity as well as cultural symbol ${ }^{30}$.

iv. Recognition: Kola nut is used to trace seniority among constituting members of the family, village or community. In a gathering, when kola nut is presented by the host, it is passed round the guests in order of seniority and finally presented to the most senior person in the family, village or community as the case may be to bless the kola nut ${ }^{31}$.

v. Unifying Agent: One of the significances of kola nut is unity. On the kola nut tree, a number of pods are held in a fruit stalk. Each pod 
contains a number of kola nuts and a number of lobes are unified together to form the kola nut. These are signs of unity ${ }^{32}$.

\section{Uses and Functions of the Kola Nut}

Kola nut is highly prized in Sub Saharan Africa because of its importance in the social life and religious customs of the people in the Central and West Africa. However, it has to be observed that the Igbo of Southeastern Nigeria do not only see kola nut as the king of all fruits but they also claim and trace the origin of kola nut to Igboland. This section will focus on the general usage of the kola nut: its social, spiritual, medicinal and economic functions to the Igbo and the world at large.

\section{The Social Values of Kola Nut}

Kola nut is used virtually in all ceremonies in Igbo society where people gather to celebrate one aspect of their value system or another. The offering of kola nut often precedes other activities during any occasion. As a social regulator, kola nut is used to lodge complaints against a fellow citizen who is found to be troublesome. The complaint would use the kola nut to inform his kindred of the issue at stake. The kola nut would be first broken and eaten before the full message is narrated. Similarly, the Igbo believe that the act of presentation of the kola nut to a guest, with the indispensable prayer, Igo Oji (kola nut prayers), the splitting and eating of the kola nut by both the host, the guest, constitute a convenant (Igba ndu). It is believed that after sharing the kola nut, neither party would contemplate harming the other, because of the Igbo belief in the supernatural origin of the kola nut. The Igbo hold the view that it can kill any party that contravenes the covenant which they freely entered into by sharing the kola nut ${ }^{33}$. 


\section{Spiritual or Ritual Values of Kola Nut}

There is a great sacredness associated with Cola acuminata (Oji Igbo) because the Igbo believe that the breaking of the kola is an invitation of the supernatural to be part of the activities of the living and bear witness in any occasion they are summoned. According to Obineche $^{34}$, the living and the dead share or partake of kola nut. The ancestors, deities and malingering spirits are requested to share from the kola nut and allow the living unmolested. It is in this regard that kola nut is traditionally seen as sacred nut which is used as a link to communicate with the gods (spirit beings), hence, it was chosen by the elders as the king of all seeds. In such prayers (rituals), bits of the kola nut are waved over the head in symbolism, expressing the exchange of kola nut for life and thrown out to the spirits and the ancestors. The diviners need kola nut to appease and seek the favour of their invisible spiritual agents in their professional routines. Upon suspicion of any laxity in the responses of the spirits to his operations, the diviner is forced to present more kola nuts to awaken them from their slumber or sleep since it is believed that the kola nut drives away sleep even among spirits as among the living. In such cases, the diviner may even chew that nut and spit it on all the items that represent the deities in the shrine.

\section{Medicinal Values of Kola Nut}

Kola nut, bitter kola and alligator pepper are traditional plants which are often eaten as snacks especially among the elderly in Nigeria. Traditionally, these nuts were chewed as a masticatory substance, to stimulate the flow of saliva but are now widely consumed as snacks in West and Central Africa. In traditional medicine, kola nut and bitter kola are dried, grounded and mixed with honey to make a traditional cough mixture ${ }^{35}$. The bitter and stringent flavor of kola nut according to Onwu-Otuyelu ${ }^{36}$ is used as digestive aid before meals to stimulate gastric juice and bile production. Also, its caffeine and theobromine 
content make it a potent neuro-stimulant that is used to combat fatigue. This was the reason why among the West African elites in those days, tins of cigarette and kola nuts are complementary items of conspicuous consumption. It was popularly known as Acada biscuits (Academic biscuits) as a euphemism for kola nut coined by and current among West African students. This is against the background of the students' convictions that kola nuts are needed to prevent fatigue to sustain and encourage longer and more mental demand for academic work.

\section{Economic/Industrial Values of Kola Nut}

Kola nut is an important economic cash crop to a significant proportion of Nigerian population who are involved in kola nut farming, trading, and industrial utilization. Kola nut has for hundreds of years served as an important article of internal trade in Nigeria and other parts of Africa. It has been an item of trade in West Africa and in the trans-Saharan trade routes for many centuries. There is also increasing demand for its usage in pharmaceutical industries and for production of soft drinks, wines, and candles. Its uses have inevitably created a high demand in excess of its production ${ }^{37}$. Since the Pharmacist, John Styth Pemberton in May, 1886, created the first coca-cola recipe, kola nut has remained the distinctive source of flavor for colas, and certain brands of soft drinks and tonics around the world. Today, coca-cola company is one of the richest companies around the world and a household name in drinks and tonic entertainment around the world. Even today, when it is purportedly claimed that coca-cola no longer uses kola nut for its drinks, but other alternatives like synthetic derivatives for its flavours, kola nut remains their historic beginning ${ }^{38}$. Therefore kola nut has a great economic/industrial importance. 


\section{Kola Nut and the Influence of Modernization}

The advent of colonialism in Igboland brought far reaching consequences. The modification in Igbo culture resulted to serious ramifications. The ramifications were visible in terms of religion, social structure, language and the Igbo worldview. And the kola nut was one of the major victims of the waves of change in the sense that the sacredness of the kola nut was violated. This sacredness according to Ezeugo ${ }^{39}$ is observed from the planting, nurturing, plucking, breaking and other aspects of kola nut even to its tree, wood and leaves. Women were forbidden from planting, climbing, plucking or breaking of kola nut. Similarly, Emeh $^{40}$ laments that the ritual dimension of the kola nut had been adulterated by some "Westernized" individuals. According to him, these overzealous individuals often invoke the name of Jesus when kola nut is being offered to God, the gods and the ancestors. This exercise is a manifestation of extreme culture corruption and mutilation arising from deep inferiority complex. It is also a result of excessive detribalization.

It is an established tradition in Igboland that the kola nut does not understand any other language except Igbo when being used for prayers or thanksgiving; but today, the educated elite had corrupted this age-long tradition. For instance, an elderly Igbo "westernized" professor was given a kola nut to pray in order to invite the blessings of God, the gods and the ancestors, the professor decided to use English. According to him, kola nut belongs to the traditional societies where customs and culture are observed; any kola nut that defies that the traditional abode and enters the university must attend school, understand and speak English fluently. With this logic, the professor went ahead to defile the ancient tradition. In as much as we may not be able to return Igboland to pre-colonial era, there is need for us to preserve those of our cultures that survived colonial intrusion, and kola nut is one of such symbols. 
Unya: The Historical Significance and Role of the Kola Nut among the Igbo of Southeastern Nigeria

\section{Conclusion}

In this study, we have argued that the kola nut is an important fruit in West Africa which is offered as a mark of hospitality, and considered as an important gesture of friendship and comradeship. But among the Igbo of Southeastern Nigeria, the kola nut occupies an exalted position - often seen as the king of all fruits on earth. To the Igbo, the act of presenting, offering and breaking of kola nut constitutes in itself a serious ritual enactment. This significance of kola nut among the Igbo is seen in their ancestral claim that the kola nut originated in Igboland, hence, the people see the kola nut as the universal symbol and identity of acceptance, cooperation and solidarity.

Again, there is this erroneous belief that the kola nut has Western origin as a result of the role it played in the emergence of Coca-Cola drink. In an attempt to get around local laws prohibiting the sale of alcohol in the 1880s, John Pemberton, the Georgian pharmacist, took caffeine extracted from kola nuts and cocaine-containing extracts from coca leaves and mixed them with sugar, other flavorings, and carbonated water to invent Coca-Cola, the first cola soft drink. Since the kola nut's majestic role in birthing Coca-Cola, many people around the world do not know that the kola nut also plays a bigger role in the life and culture of West African people where it originated $^{41}$. If this present study brings to the fore the West African origin and the role the kola nut plays among the African people, then, the objective of study might have been achieved in part.

Having observed earlier that the kola nut belongs to the group of indigenous African tradition that survived the colonial intrusion and destruction of African way of life, the threat on the kola nut is still on the increase. For instance, in most African families, the kola nut no longer serves as the instrument of hospitality and acceptance which must be presented to one's guest. The urban and city dwellers and even those in the village now have alternative means of entertaining their guest with European products such as biscuits, soft drinks and 
wines. They do not resort to European products because of their hatred for kola nut; rather, the kola nut is becoming a scarce product. In the precolonial Africa, almost all families in Igboland had their own kola nut trees, and the elders made sure that all the rituals associated with the planting, presenting and breaking of kola nut are observed.

Apart from the unavailability aspect of the kola nut, there is this modern fear that the kola nut might be used as an instrument of wickedness if the host decides to poison the kola nut before presentation especially in social ceremonies outside the traditional setting. Therefore, if the significance and values of the kola nuts must be preserved and sustained by the Igbo, the study recommends the following:

a. The Igbo collectively and individually should revive the culture of planting kola nut to ensure its availability and affordability at all time.

b. Parents should encourage their children especially the male to always observe the proceedings of sharing the kola nut and the prayers associated with the kola nut when it is in progress in their families.

c. The government should also be involved in kola nut farming and production, if not for social purposes, at least for industrial usage.

d. The symposiums on kola nut and other African heritages should not be limited to only the Institute of African studies in our higher institutions, rather, community leaders and town unions should also be encouraged to be holding annual lectures on the place of kola nut in the life of an Igbo man.

To be sure, the Igbo of Southeastern Nigeria has traditional unifying factors they all commonly subscribe to. And the kola nut protocol is one of the main tenets that are shared by all the Igbo speaking people. Therefore, the kola nut tradition should be encouraged since it affords individuals the opportunity to interact with other community members regardless of class affiliations. 
Unya: The Historical Significance and Role of the Kola Nut among the Igbo of Southeastern Nigeria

\section{References}

1. Quarco, T. Development of Koal and Its Future in Nigeria. Proc. Agric. Soc. Nigeria. Vol.6., 1969.

2. Lovejoy, P.E. "Kola Nuts: The Coffee of Central Sudan". In Goodman, J., Lovejoy, P.E. and Sheratt, A. (eds) Consuming Habits: Drugs in History and Anthropology. Oxon: Routledge, 2007.

3. Sprague, K. The Kola Nut: West African Commodity in the Atlantic World. African Study Centre, Los Angeles, USA, 2018.

4. Quarco, T. A Handbook on Kola. CRIN, Ibadan, 1973.

5. Asogwa, E.U., Anikwe, J.C. and Mokwunye, F.C. Kola Production and Utilization for Economic Development. African Scientist, Vol.7, No.4, 2006.

6. Basden, G.T. Among the Ibo's of Nigeria. London: Frank Cass and Company, 1966.

7. Nwachukwu, M. What is this about Kolanut in Igboland? Vanguard Newspaper, April, 12, 2012.

8. Obineche, J.O. Kola Nut: Revisiting the Igbo Socio-Cultural Values and Identity. International Journal of Arts and Humanities (IJAH) Bahir Dar-Ethiopia, Vol.6(2), S/No.21, 2017.

9. Achebe, C. There was a Country: A Personal History of Biafra. London: Penguin Press, 2012.

10. Kammampoal, B. and Laar, S. The Kola Nut: Its Symbolic Significance in Chinua Achebe's Things Fall Apart. International Journal on Studies in English Language and Literature (IJSELL) Vol.7, No.8, 2019.

11. Ukaegbu, J.O. The Kola Nut: As an Igbo Cultural and Social Symbol. The Igbo Network, 2019.

12. Obineche, J.O. Kola Nut: Revisiting the Igbo Socio-Cultural Values and Identity. Op.cit.

13. Onwu-Otuyelu, C.A. Good Morning Mr. Kola Nut. Lagos: Malt House Press Limited, 2009. 
14. Ibid

15. Obineche, J.O. Kola Nut: Revisiting the Igbo Socio-Cultural Values and Identity. Op.cit.

16. Umeogu, B.C., Onebunne, J.I., Ojiakor, C.I., and Etodike, C.E. Kola Nut and Symbolismic Universe: Towards the Creation and Constitution of Igbo Science and Arts. Canadian Social Science, 15(4), 2019.

17. Obineche, J.O. Kola Nut: Revisiting the Igbo Socio-Cultural Values and Identity. Op.cit.

18. Ibid

19. Umeogu, B.C., Onebunne, J.I., Ojiakor, C.I., and Etodike, C.E. Kola Nut and Symbolismic Universe: Towards the Creation and Constitution of Igbo Science and Arts. Op.cit.

20. Ibid

21. Kammampoal, B. and Laar, S. The Kola Nut: Its Symbolic Significance in Chinua Achebe's Things Fall Apart. op.cit.

22. Ezeugo, S.N.I.U. Research and Comments on Igbo Culture. Unpublished Art, 1985.

23. Basden, G.T. Among the Ibos of Nigeria. Lagos: University Publishing Co, 1983.

24. Obineche, J.O. Kola Nut: Revisiting the Igbo Socio-Cultural Values and Identity. $O p$.cit.

25. Ibid

26. Achebe, C. Things Fall Apart. Ibadan: Heineman, 1958.

27. Umeogu, .B.C., Onebunne, J.I., Ojiakor, C.I. and Etodike, C.E. Kola Nut and Symbolismic Universe: Towards the Creation and Constitution of Igbo Science and Arts. Op.cit.

28. Achebe, C. Things Fall Apart. op.cit.

29. Ibid

30. Umeogu, B.C., Onebunne, J.I., Ojiakor, C.I. and Etodike, C.E. Kola Nut and Symbolismic Universe: Towards the Creation and Constitution of Igbo Science and Arts. op.cit. 
Unya: The Historical Significance and Role of the Kola Nut among the Igbo of Southeastern Nigeria

31. Ekwueme, S.C., Udagha, N. and Mokwenye, E.M. Kolanut Ritual and Women in Igbo Culture. Ikoro Journal of Contemporary African Studies, Vol.14, No.1., March, 2020.

32. Ibid

33. Chigbo, M.A. "The Value and Significance of Kolanut Among the Igbo". In Onwuka, J.O. and Ahaiwe, S.C. (eds) Nigerian Heritage. Okigwe: Whytem Publishers (Nig), 1997.

34. Obineche, J.O. Kola Nut: Revisiting the Igbo Socio-Cultural Values and Identity. op.cit.

35. Adebayo, S.A. and Oladele, O.I. Medicinal Values of Kolanut in Nigeria: Implication for Extension Service Delivery. Life Science Journal, Vol. 9, No.2, 2012.

36. Onwu-Otuyelu, C.A. Good Morning Mr. Kola Nut. Op.cit.

37. Ndagi, I., Babalola, F.D., Mokwunye, I.U., Anagbogu, E.U., Idrisu, M. and Mokwunye, F.C. Potentials and Challenges of Kolanut Production in Niger State, Nigeria. International Scholarly Research Notices, 2012.

38. Obineche, J.O. Kola Nut: Revisiting the Igbo Socio-Cultural Values and Identity. op.cit.

39. Ezeugo, S.N.I.U. Research and Comments on Igbo Culture. Unpublished Art. op.cit.

40. Emeh, C. Benefits of African Economic Integration. The Independent, 2019.

41. Obineche, J.O. Kola Nut: Revisiting the Igbo Socio-Cultural Values and Identity.

Ikenna Ukpabi Unya (PhD) is a lecturer in History Unit, School of General Studies, Michael Okpara University of Agriculture, Umudike, Umuahia, Abia State. 